\title{
Relationships between University Performances and Economic Growth
}

\author{
Zoljargal Dembereldorj ${ }^{1}$, Garmaa Dangaasuren ${ }^{2} \&$ Davaa Jagdag $^{3}$ \\ ${ }^{1}$ Center of Foreign Languages, Division of Humanities, School of Arts and Sciences, National University of Mongolia, \\ Mongolia \\ ${ }^{2}$ Institute for Human Development and Education, NGO, Mongolia \\ ${ }^{3}$ Department of Pedagogy and Psychology, Division of Social Sciences, School of Arts and Sciences, National \\ University of Mongolia, Mongolia \\ Correspondence: Zoljargal Dembereldorj, Center of Foreign Languages, Division of Humanities, School of Arts and \\ Sciences, National University of Mongolia, Mongolia
}

Received: July 18, 2018

Accepted: August 10, 2018

Online Published: August 14, 2018

doi:10.5430/ijhe.v7n4p123

URL: https://doi.org/10.5430/ijhe.v7n4p123

\begin{abstract}
Universities play an important role in the economic development - knowledge economy. Previous studies proposition that universities significantly contribute to the economic development of the countries. Countries implement policies to efficiently connect higher education and the economy. This study explores the relationships between the university performances measured by the world university rankings and the gross domestic product. We employed the data from the World Bank and two university rankings for a period of 2011-2016. We ran correlation analysis followed by t-test analysis for confirming the linear and non-linear relationship. For robustness, we used chi-squared test for independence. The result shows there is a positive non-linear relationship between university performances and GDP. Indicators for citation and research suggests the quality of the research matters more than the mere research and publications. We may conclude that the "research quality" of the university intensive in researching can contribute indirectly to the economic development of the countries.
\end{abstract}

Keywords: university rankings, gross domestic products, university performances, relationship, economic growth

\section{Introduction}

Universities play an essential role in the current economic paradigm of higher education. Scholars document that higher education institutions are the main gear of the knowledge economy (Olssen\& Peters, 2005; Marginson, 2009) or the new economy (Slaughter \& Leslie, 1997; Slaughter \& Rhoades, 2004). Universities produce knowledge as a raw material which can be used or "innovated" in business industries for economic benefits. For this, states and governments have been designing and implementing policies that encourage cooperation between universities and business industries to increase their economic capabilities. Thus, it is expected that higher education institutions universities are engaged in commercialising themselves and capitalising knowledge for the benefits of the society to boost the economy.

The relationship between economy and the universities as a creator of new knowledge is assumed in the theory of academic capitalism (Slaughter \& Leslie, 1997; Slaughter \& Rhoades, 2004) as well as the Triple Helix of university-industry-government relationship (Etzkowitz, 2003). The theory of academic capitalism explains the integration process of the universities into the new economy. Model of Triple Helix of university-industry-government explains the process of innovation through the relations among three major institutions of the knowledge economy: university, industry, and government. Nevertheless, both theories assume that there is a positive relationship between universities and economic development.

This assumption is little explored in previous studies. Within the framework of neoliberalism and knowledge economy, studies examined networked research relations in South Korea (Park \&Leydesdorff, 2010), a role of entrepreneurial universities for economic growth in Singapore (Wong, Ho \& Singh, 2007), wealth generation of the universities across different regions in the UK (Huggins \& Johnston, 2009), economic contribution of local universities in the USA (Bramwell\& Wolfe, 2008), economic promotion of entrepreneurial universities in Germany (Mueller, 2006) and so on. These studies approach the issues of university role in the economic development from the network or entrepreneurship aspect. However, it is little examined empirically if there is a relationship between 
university performances and the economic growth indication of gross domestic products to estimate actual economic interplays between university performance and the countries' economic capability.

The purpose of the study is to explore if there is a strong relationship between the university performances and the actual gross domestic product measurement. Here we ask "Is there an actual link between university performances and the economic growth of the country? If so, to what extent is there a relationship between the university performances and the economic growth? How do those relationships differ across the time span of recent 6 years? These questions help to understand the relationship between university performances and economic growth. One of the main indicators of the university performances is world university rankings whereas the gross domestic products can serve as an indicator of countries economic growth. We reviewed the most relevant literature on the contribution of the university to the economic development.

\section{Literature Reviews}

A role of universities is essential in the economic growth of the countries. Power \&Malmberg (2008) argued that the role of a university in regional economic development is to possess a world class university which creates an abundance of material and immaterial resources through excellence in research, excellence in education and excellence in collaboration with private and public actors. Another study found that research universities generate knowledge spillovers which can be capitalised and induce the growth of the regional economy (Goldstein \&Reanult, 2004). Bramwell\& Wolfe (2008) documented that local research-intensive universities indeed contribute to the economic development through the intermediaries such as business industries. They identified mechanisms that facilitate business, and eventually economy, to flourish - attracting and retaining talented students, research, and development, global or international knowledge exchanges through faculties and university policies to innovate. These mechanisms connect university and industries which further impact regional economy. Thus, studies provide evidence for the proposition that universities positively impact the economic development of the region.

Some studies explored intermediaries between universities and economic development in terms of talented students (Florida \& Cohen, 1999), research output (Bessette, 2003), university research collaboration (Berman, 1990, Perkman\& Walsh, 2007), university technology transfer offices (Seigel,et al, 2003), innovation (Cainelli, et., al, 2004) and so on. They maintain that there is a relationship between universities and industries which local, regional or country's economy benefits. Despite the good number of studies on relationships of universities and industries to boost economic capability, there are few studies examining the relationship universities measured by the world ranking systems and the economic capability measured by gross domestic product (Roessneret. et. al., 2013). Hence, the present study, first, is to explore a relationship between the university performances and the gross domestic products. Second, it is to test the assumption that universities contribute to the economic development propositioned by the theory of academic capitalism.

Academic capitalism can be understood as a way that higher education institutions respond to the new economy or the neoliberal state. Neoliberal states value the role of the market in the society, thereby appreciating economic exchanges and benefits of the organizations. Slaughter \& Rhoades (2004) emphasised the role of universities in the new economy and proposed the theory of academic capitalism. The theory explains how universities capitalise their functions and pursue economic benefits usually by the means of knowledge production. In the new economy, knowledge is seen as a raw material that can be circulated in the market with economic returns, thereby elevating economic development of the country. Knowledge as a raw material is produced in the university and is circulated through networks such as patenting and copyrights. Thus, the new economy and the university performances are assumed to be correlated.

There are salient characteristics of the new economy: global scope, knowledge as raw material, non-Fordist manufacturing, educated workers, and technology savvy consumers, neoliberal state, circuits of knowledge, interstitial organisational emergence, intermediating networks, extended managerial capacity, market behavior, and professional strategies (Slaughter \& Rhoades, 2004).

Since we focus on the association of the university performances and the economic development, we need to elaborate on university performances and world university rankings as a performance measurement. Altbach (2009) identified that research universities include a cadre of full-time faculty, academic freedom, a salary structure permitting a local middle-class lifestyle, promotion and salary enhancement based on performances rather than just seniority, reasonable guarantees of long-term appointment, absence of corruption in all the sectors of academic work, and an academic culture of competition and research productivity. Schwartzman (2007, p.163) organised the main characteristics to be first, world class research or internationally recognised, second, freedom of research, teaching and expression, third, academic autonomy and forth, money or funding. Meanwhile, well-known universities are 
known as world class universities with which the fame has been gained by the marketisation of world university rankings.

Many studies documented that governments have paid special attention to build a "world class research university." Mok and Chan (2008) examined the national responses and policies in higher education of China and Taiwan. They base these responses and policies as an impact of GURs which leads both countries to pursue "world class university" initiatives. China and Taiwan approached pragmatically to build a "world class university" for benchmarking with global top universities. In the same vein, Yonezawa (2011) examined the Japanese response to GURs. As one its world class pursuit, Japanese government prioritised internationalisation of higher education. The Fukuda Cabinet (2007-2008)the government have set up a plan to invite 300,000internationalstudents by 2020. South Korea is implementing three major policies for the pursuit of a world class university: Brain Korea 21 or BK21, World Class University or WCU project and Study Korea project. Brain Korea 21 is to enhance research activities, WCU is designed to import prominent scholars and Study Korea project is to recruit international students. They produced more favorable conditions for Korean universities to become WCUs (Byun et. al., 2013), despite the fact that there were other consequences for the pursuit of "world class university." In Singapore, Xavier and Alsagoff (2013) documented the National University of Singapore was using a strategy of an international alliance by holding cooperation and official relations with top universities abroad; research achievements by emphasising areas of medicine, technology, science and engineering; and developing global students by emphasising exchange programs in other universities. Hazelkorn (2009) identified changing actions in research, changes in organisational structure, the curriculum that bridges EU and US model, target Ph.D students and internationalisation, hire talented scholars and changes in management and marketing of higher education institutions. The world class university approach has been aggressively pursued in many other countries as world university rankings demonstrate "the best performers" of the universities annually.

The popularity of world university rankings is explained by the globalisation and the rising awareness of knowledge economy in the society. Marginson (2009) explained how knowledge economy had changed the world order of higher education with an order of knowledge production. According to Marginson (2009), knowledge economy consists of production, exchange, circulation of knowledge and information. In contemporary capitalist economy, knowledge produced in the universities is hard to nail down as economic property (Marginson, 2009). At this point, knowledge should be commodified and sorted out in commercial markets. Kehm and Stensaker (2009) viewed that rankings are a symptom of emerging knowledge economy. The function of ranking in this perspective is that of a structuring device of knowledge (Stensaker\&Kehm, 2009). Similarly, Margison (2010) argued that global knowledge is giving a rise of the global culture of comparisons in higher education. One of the main functions of global comparison of higher education is that they provide information by indicating proxy for the research capability of higher education institution (Marginson, 2010). Moreover, Hazelkorn(2013) advocated that first, university rankings are a simple and easy comparison of education production and performance; second, they have become a major tool for measuring educational quality and excellence; and third, they indicate the global competitiveness. World university rankings thus have become one of the external evaluation tools (Slaughter \& Rhoades, 2004, p. 24) to measure the performances of the world universities.

There are few studies that have examined relationships or impacts of higher education and the gross domestic products. Huang et., al. (2009) examined university enrollment rate with the actual gross domestic product over the years of 1972-2007 in China. They concluded that mere increase in enrollment does not affect economic growth, but higher education should align more with the knowledge based approach. Another study found curricula or disciplines are related to gross domestic product positively and significantly except for the humanities discipline in Taiwan throughout the year of 1965-2000 (Lin, 2004). Similarly, there is a positive relationship between enrollment and gross domestic product per capita for Cambodia (Veracheat \& Dash, 2011); and there is a positive and significant relationship between human capital and gross domestic product per capita evidenced in the data of 1960-2000 in case of Africa (Gyimah-Brempong et., al. 2006). These studies document positive relationships between economic growth and higher education from the perspective of human capital. However, it is unclear if higher education as a knowledge producer bears a positive relationship with economic growth of the region or countries.

The present study explores the relationship between higher education -university performances, and the economic growth - gross domestic products. If we succeed to estimate the extent of the relationship and type of the relationship between university performances, and the economic growth, it may provide us with another perspective to look at the policies and strategies of the countries for supporting higher education and the role of universities into the economic development. We also attempt to use world university rankings as a measurement of university performance and 
examine them in terms of economic growth. Moreover, we test the conventional view of universities' contribution to the economic growth in the knowledge-based economy. Hence, this study may have both theoretical and practical significance in higher education policies and economic strategies.

\section{Methods}

\subsection{Data}

To understand the relationship between university performances and economic growth, we utilised the data from world university rankings and gross domestic products from the World Bank Database. We collected data from the global university rankings to measure university performances. We selected two major world university rankings: Academic Ranking of World Universities (ARWU), and Times Higher Education World University Rankings (THE) throughout the years of 2011-2016.

The main reason to select ARWU and THE is the credibility of the study. ARWU is a ranking system established in an Asian context, the Shanghai Jia Tong University in China, whereas the THE is a ranking system established in an Western context, The Times Higher Education magazine in the United Kingdom. The selection of these two rankings for the present study is not a comparison of the rankings, rather a variety of the ranking systems to establish credibility.

Indicators of the ARWU utilised in this study are alumni, award, HiCi, N\&S, PUB, PCP. Alumni indicates the total number of the bachelors, masters and doctoral degree earners in higher education institutions winning Nobel Prizes and Fields Medals; award indicates the total number of faculty members in higher education institutions winning Nobel Prizes in Physics, Chemistry, Medicine and Economies and Field Medal in Mathematics; HiCi is the number of highly cited researchers according to Clarivate Analytics; N\&S is "the number of papers published in Nature and Science between 2012 and 2016;" PUB is "the total number of papers indexed in Science Citation Index- Expanded and Social Science Citation Index in 2016; and PCP is "the weighted scores of the above five indicators divided by the number of full-time equivalent academic staff" (ARWU, 2018). Total 100 percent of the ranking is distributed to be alumni 10 percent, award is 20 percent, HiCi 20 percent, N\&S 20 percent, PUB 20 percent, and PCP 10 percent (ARWU, 2018).

THE claims to apply 13 carefully calibrated indicators to measure the performance of research intensive universities. The indicators are teaching reflecting the learning environment; research indicating volume, income and reputation; citations indicating research influence; international outlook indicating staff, students and research; and Industry income reflecting knowledge transfer (THE, 2018). Teaching includes reputation survey of 15 percent; staff-to-student ratio of 4.5 percent; doctorate-to-bachelor's ratio of 2.25 percent; doctorates-awarded-to-academic-staff-ratio of 6 percent; and institutional income of 2.25 percent (THE, 2018). Research includes reputation survey of 18 percent; research income of 6 percent; and research productivity of 6 percent (THE,2018). International outlook includes international-to-domestic student ratio of 2.5 percent, international-to-domestic staff ratio of 2.5 percent, and international collaboration of 2.5 percent; whereas citations and industry income preserve 30 percent and 2.5 percent respectively (THE, 2018). Thus, teaching is 30 percent, research is 30 percent, citation is 30 percent, international outlook is 7.5 percent and industry income is 2.5 percent totaling 100 percent in the ranking (THE, 2018).

Moreover, the values of university performances were varied due to the data availability presented in two rankings. ARWU presented top 200 universities with detailed ratings in their rankings, thus enabling us to estimate 100 top universities performance annually. THE presented top 200 universities with detailed ratings in their rankings, thus enabling us to estimate 200 top universities performance annually. In total, we made our analysis using 300 values of the university performances with double counting.

The annual result of the university rankings was imperative to select countries from the world bank data bank in analysing the relationship between university performances and economic growth measured by gross domestic products. The data for measuring economic growth were obtained from the World Bank data bank: gross domestic product - GDP of the country through the years 2011-2016. Depending on the annual university rankings result, the number of countries with respective value for gross domestic product was different: there were 25 country values for gross domestic products in 2011, 26 in 2012, 24 in 2013, 26 in 2014, 28 in 2015 and 27 in 2016 in the ranking of the Times Higher Education. The ranked universities are located in Australia, Austria, Belgium, Brazil, Canada, China, Denmark, Egypt, Finland, France, Germany, Hongkong, Ireland, Israel, Italy, Japan, Netherlands, New Zealand, Norway, Singapore, South Africa, South Korea, Spain, Sweden, Switzerland, Taiwan, Turkey, the United Kingdom, and the United States. Similarly, ARWU included values of 18 countries for gross domestic products in 2016 and 16 
in the rest of the years. The countries are Australia, Belgium, Canada, China, Denmark, Finland, France, Germany, Israel, Japan, Netherlands, Norway, Russia, Singapore, Sweden, Switzerland, the United Kingdom, and the United States.

\subsection{Analysis and Results}

We employed statistical techniques of correlation analysis, t-test, and chi-squared test for our analysis. Mean value of 6 years for the gross domestic product was $7.35 \mathrm{E}+12$ and $\mathrm{St} . \mathrm{D}=7.31 \mathrm{E}+12$ for the case of Times Higher Education; the mean value of 6 years for the gross domestic product was $9.77 \mathrm{E}+12$ and $\mathrm{St} . \mathrm{D}=7.59 \mathrm{E}+12$ for Academic Ranking of World Universities. Mean value of university rankings for 6 years in total score was 59.82 and St.D=12.44 for Times Higher Education; whereas the mean value for Academic Ranking of World Universities was 36.06 and St.D=12.19.

First, we ran correlation analysis for gross domestic product and two university rankings, respectively. For our analysis, we employed top 200 universities from the Times Higher Education rankings over the years of 2011-2016, and top 100 universities from the Academic Ranking of World Universities over the same year span. In accordance with the top ranked universities, we selected samples of gross domestic product for countries with high ranked universities. Values for the gross domestic product were divided into 5 and 4 groups, whereas indicators of university rankings into 7 and 5 groups on a yearly basis for the Times Higher Education rankings and the Academic Ranking of World Universities respectively. The following is the equation for correlation formula:

$$
r=\frac{\sum_{i=1}^{k} \sum_{j=1}^{m} n_{i j}\left(x_{i}-\bar{x}\right)\left(y_{j}-\bar{y}\right)}{\sqrt{\sum_{i=1}^{k} n_{i}\left(x_{i}-\bar{x}\right)^{2}} \sqrt{\sum_{j}^{m} n_{j}\left(y_{j}-\bar{y}\right)^{2}}}
$$

For this, $k$ is the value of the groups for gross domestic product, $m$ is the value of the groups for ranking indicator scores, $n_{i j}$ is the frequency of values, $n_{i}$ is total frequency of $i$ th group of indicator values; $n_{j}$ is total frequency of $j$ th group of gross domestic product; $x_{i}$ is mean value of $i$-group, $y_{j}$ is mean value of $j$-group, $\bar{x}$ is total mean value of indicators, and $\bar{y}$ is total mean of gross domestic product.

Using the above formula, we calculated the correlation coefficient of the gross domestic product of the country and university ranking indicators respectively. Table 1 and 2 show the correlation coefficient of gross domestic product and two world rankings with respective indicators.

Table 1. Correlation coefficient of Times Higher Education

\begin{tabular}{lllllll}
\hline \multirow{2}{*}{ GDP per year } & \multicolumn{7}{l}{ Times Higher Education } & & & \\
\cline { 2 - 7 } $\mathbf{2 0 1 6}$ & Total & Citation & Outlook & Income & Research & Teaching \\
$\mathbf{2 0 1 5}$ & 0.300 & 0.356 & -0.553 & -0.069 & 0.207 & 0.230 \\
$\mathbf{2 0 1 4}$ & 0.243 & 0.314 & -0.565 & -0.074 & 0.141 & 0.280 \\
$\mathbf{2 0 1 3}$ & 0.274 & 0.380 & -0.611 & -0.134 & 0.150 & 0.280 \\
$\mathbf{2 0 1 2}$ & 0.213 & 0.393 & -0.647 & -0.113 & 0.149 & 0.260 \\
$\mathbf{2 0 1 1}$ & 0.310 & 0.440 & -0.668 & -0.039 & 0.214 & 0.310 \\
\hline
\end{tabular}

Table 2. Correlation coefficient of Academic Ranking of World Universities

\begin{tabular}{llllllll}
\hline \multirow{2}{*}{ GDP per year } & \multicolumn{7}{l}{ Academic Ranking of World Universities } \\
\cline { 2 - 8 } $\mathbf{2 0 1 6}$ & Total & Alumni & Award & HiCi & N/S & Pub & PCP \\
$\mathbf{2 0 1 5}$ & 0.314 & 0.173 & 0.202 & 0.412 & 0.362 & 0.052 & 0.112 \\
$\mathbf{2 0 1 4}$ & 0.322 & 0.052 & 0.201 & 0.581 & 0.434 & 0.152 & 0.043 \\
$\mathbf{2 0 1 3}$ & 0.312 & 0.051 & 0.213 & 0.581 & 0.440 & 0.124 & 0.052 \\
$\mathbf{2 0 1 2}$ & 0.331 & 0.103 & 0.220 & 0.624 & 0.440 & 0.134 & 0.081 \\
$\mathbf{2 0 1 1}$ & 0.332 & 0.071 & 0.207 & 0.615 & 0.398 & 0.176 & 0.106 \\
\hline
\end{tabular}


The correlation of gross domestic product from years 2011 to 2016 and world university rankings is shown to be ranged 0.213 to 0.350 for Times Higher Education, 0.312 to 0.348 for Academic Ranking of World Universities. The correlation coefficient is relatively weak for both university rankings and gross domestic product. Weak correlation indicates that there is a non-linear relationship, but not necessarily no relationship.

We calculated associations of each indicator of both global rankings respectively. From all indicators of the Times Higher Education ranking, a citation indicator has the most correlative coefficient ranging from 0.288 to 0.440 with positive relationship. Indicators of international outlook and income are shown to have a negative relationship with the gross domestic product in which international outlook has the moderately negative strong relationship with the gross domestic product ( $r$ is from -0.668 to -0.402). A relationship between research and the gross domestic product is a positive very weak correlation ranging from 0.141 to 0.279 , whereas an indicator of teaching has a positive weak correlation with the gross domestic product ranging from 0.230 to 0.340 .

On the other hand, all indicators of the Academic Ranking of World Universities are positively correlated with the gross domestic product. The correlation coefficient of alumni is ranged between 0.071 to 0.173 ; and, similarly, award 0.201 to 0.220 . HiCi or highly cited researchers has the strongest positive correlation with the gross domestic product among all the indicators ( $0.412-0.627$ ). Next, strong positive correlation is $\mathrm{N} \& \mathrm{~S}$ or number of papers published in Nature and Science with coefficient ranging from 0.362 to 0.440 . "Pub" or the total number of papers published in Social Science Citation indexed and Science Citation indexed journals is associated very weakly with coefficient ranging from 0.052 to 0.217 ; similarly, $\mathrm{PCP}$ or the weighted score of all five indicators divided by faculty is between 0.094 to 0.112 . Overall, there is a very weak to weak correlation between indicators of both rankings with the gross domestic product. However, we can observe that there is a moderately strong positive correlation of citation related indicators of both rankings; and moderately strong negative correlation of international outlook which indicates international collaboration and the ratio of international students and faculty members.

Following the correlation analysis, we examined if the above association is true by running $T$-test. Since the correlation coefficient is almost near to zero, we tested the null hypothesis that there is no significant relationship between gross domestic product and university performances.

If $\left|t_{n-2}\right| \geq t_{1-\alpha / 2} \quad$ (2) is proved, then the null hypothesis is rejected. We set $\mathrm{p}$ value at 0.05 . $T$-test distribution quintile value is $t_{1-\alpha / 2}=1.959$. We can see that many indicators of the Time Higher Education Rankings except for the indicator of income satisfy the above condition (2). As for the Academic Ranking of World Universities, total score for $\mathrm{p}$ value is 0.00 , whereas the specific indicators of Award (p-0.046, 0.035, 0.032, 0.027, 0.038, 0.035), HiCi (p-0.000 throughout the selected years) and $N \& S$ (p-0.000 throughout the selected years) are shown to be significantly associated. $p$ value for other indicators is higher than 0.05 . In general, the relationship between the gross domestic product and the university performances according to the world university rankings is significant. The $T$-test estimation is shown in table 2 and 3.

Table 3. $T$-test results for Times Higher Education

\begin{tabular}{|c|c|c|c|c|c|c|c|c|c|c|c|c|}
\hline \multirow{2}{*}{$\begin{array}{l}\text { GDP } \\
\text { year }\end{array}$} & \multicolumn{2}{|l|}{ Total } & \multicolumn{2}{|c|}{ Citation } & \multicolumn{2}{|l|}{ Outlook } & \multicolumn{2}{|l|}{ Income } & \multicolumn{2}{|c|}{ Research } & \multicolumn{2}{|c|}{ Teaching } \\
\hline & $\mathrm{t}$ & $\mathrm{p}$ & $\mathrm{t}$ & $\mathrm{p}$ & $\mathrm{t}$ & $\mathrm{p}$ & $\mathrm{t}$ & $\mathrm{p}$ & $\mathrm{t}$ & $\mathrm{P}$ & $\mathrm{t}$ & $\mathrm{P}$ \\
\hline 2016 & 4.425 & 0.0 & 5.360 & 0.0 & -9.339 & 0.0 & -0.973 & 0.33 & 2.977 & 0.0 & 3.325 & 0.0 \\
\hline 2015 & 3.524 & 0.0 & 4.653 & 0.0 & -9.635 & 0.0 & -1.04 & 0.29 & 2.004 & 0.046 & 4.247 & 0.0 \\
\hline 2014 & 4.008 & 0.0 & 5.798 & 0.0 & -10.860 & 0.0 & -1.90 & 0.05 & 2.134 & 0.034 & 4.215 & 0.0 \\
\hline 2013 & 3.067 & 0.0 & 6.013 & 0.0 & -11.939 & 0.0 & -1.58 & 0.11 & 2.120 & 0.035 & 3.914 & 0.0 \\
\hline 2012 & 4.604 & 0.0 & 6.914 & 0.0 & -12.631 & 0.0 & -0.54 & 0.58 & 3.082 & 0.002 & 4.601 & 0.0 \\
\hline 2011 & 5.274 & 0.0 & 4.231 & 0.0 & -6.177 & 0.0 & 2.76 & 0.006 & 4.088 & 0.0 & 5.138 & 0.0 \\
\hline
\end{tabular}


Table 4. T-test results for Academic Ranking of World Universities

\begin{tabular}{|c|c|c|c|c|c|c|c|c|c|c|c|c|c|c|}
\hline \multirow{2}{*}{$\begin{array}{l}\text { GDP } \\
\text { year }\end{array}$} & \multicolumn{2}{|l|}{ Total } & \multicolumn{2}{|c|}{ Alumni } & \multicolumn{2}{|c|}{ Award } & \multicolumn{2}{|l|}{ HiCi } & \multicolumn{2}{|l|}{$\mathrm{N} / \mathrm{S}$} & \multicolumn{2}{|l|}{ Pub } & \multicolumn{2}{|l|}{ PCP } \\
\hline & $\mathrm{t}$ & $\mathrm{p}$ & $\mathrm{t}$ & $\mathrm{p}$ & $\mathrm{t}$ & $\mathrm{p}$ & $\mathrm{t}$ & $\mathrm{p}$ & $\mathrm{t}$ & $\mathrm{p}$ & $\mathrm{T}$ & $\mathrm{p}$ & $\mathrm{T}$ & $\mathrm{p}$ \\
\hline 2016 & 3.227 & 0.001 & 1.707 & 0.090 & 2.020 & 0.046 & 4.450 & 0.000 & 3.819 & 0.000 & 0.495 & 0.622 & 1.095 & 0.273 \\
\hline 2015 & 3.343 & 0.001 & 0.495 & 0.623 & 2.126 & 0.035 & 7.048 & 0.000 & 4.714 & 0.000 & 1.501 & 0.133 & 0.396 & 0.690 \\
\hline 2014 & 3.227 & 0.001 & 0.495 & 0.623 & 2.126 & 0.032 & 7.048 & 0.000 & 4.714 & 0.000 & 1.501 & 0.133 & 0.396 & 0.690 \\
\hline 2013 & 3.460 & 0.000 & 0.994 & 0.321 & 2.232 & 0.027 & 7.822 & 0.000 & 4.850 & 0.000 & 1.297 & 0.192 & 0.794 & 0.425 \\
\hline 2012 & 3.460 & 0.000 & 0.694 & 0.483 & 2.094 & 0.038 & 7.720 & 0.000 & 4.294 & 0.000 & 1.769 & 0.070 & 1.055 & 0.290 \\
\hline 2011 & 3.674 & 0.000 & 0.974 & 0.332 & 2.126 & 0.035 & 7.967 & 0.000 & 4.714 & 0.000 & 2.200 & 0.030 & 0.934 & 0.350 \\
\hline
\end{tabular}

Followed the $t$-test, we examined if there is a statistically significant relationship exists between gross domestic product and global university rankings. We applied the chi-squared test and examined the independence of two variables: gross domestic product and world university rankings. For this we used the formula

$$
\chi^{2}=n\left(\sum_{i, j} \frac{n_{i j}^{2}}{n_{i} n_{j}}-1\right)
$$

$n$ is the sum of $n_{i j}$ frequencies. The probability is shown in table 3 for each university ranking. The alpha score is $\alpha=0.05$ with the degree of freedom $\mathrm{df}=24$ for Times Higher Education rankings (200 universities) and gross domestic product. Given the estimation, 36.21 is the value for rejecting the null hypothesis. For this, we applied $\chi^{2} \geq \chi_{0.05}^{2}$ (4). The test shows that the null hypothesis was not rejected for the total score of the Times Higher Education ranking except for the year of 2016. The null hypothesis was rejected statistically significantly for specific indicators: citation $\left(\chi^{2}=50.21,87.04,59.60,57.89,56.77,71.46 ; \mathrm{p}=0.00\right)$ and outlook $\left(\chi^{2}=68.59,151.65,132.84,130.17\right.$, $125.33,118.03 ; \mathrm{p}=0.00)$. In other words, citation and outlook are significantly related to the gross domestic product $\left(\min _{\text {citation }} \chi^{2}=50.21 \geq 36.41, \min _{\text {outlook }} \chi^{2}=68.59 \geq 36.41\right.$. Other indicators - research and teaching - show no relationship with the gross domestic product. However, the year of 2011 shows a statistically significant relationship between two variables as compared to later years.

Table 5. Chi-squared test results for Times Higher Education

\begin{tabular}{|c|c|c|c|c|c|c|c|c|c|c|c|c|}
\hline \multirow{2}{*}{$\begin{array}{l}\text { GDP } \\
\text { year }\end{array}$} & \multicolumn{2}{|l|}{ Total } & \multicolumn{2}{|c|}{ Citation } & \multicolumn{2}{|c|}{ Outlook } & \multicolumn{2}{|c|}{ Income } & \multicolumn{2}{|c|}{ Research } & \multicolumn{2}{|c|}{ Teaching } \\
\hline & $\chi^{2}$ & $\mathrm{p}$ & $\chi^{2}$ & $\mathrm{p}$ & $\chi^{2}$ & $\mathrm{p}$ & $\chi^{2}$ & $\mathrm{p}$ & $\chi^{2}$ & $\mathrm{P}$ & $\chi^{2}$ & $\mathrm{p}$ \\
\hline 2016 & 25.85 & 0.36 & 71.46 & 0.00 & 118.03 & 0.00 & 50.26 & 0.001 & 29.21 & 0.212 & 34.26 & 0.08 \\
\hline 2015 & 25.78 & 0.36 & 56.77 & 0.00 & 125.33 & 0.00 & 41.13 & 0.01 & 22.45 & 0.55 & 29.45 & 0.20 \\
\hline 2014 & 25.76 & 0.36 & 57.89 & 0.00 & 130.17 & 0.00 & 37.97 & 0.03 & 27.99 & 0.26 & 39.97 & 0.02 \\
\hline 2013 & 28.48 & 0.24 & 59.60 & 0.00 & & 0.00 & 24.99 & 0.40 & 26.46 & 0.33 & 30.09 & 0.18 \\
\hline 2012 & 27.01 & 0.30 & 87.04 & 0.00 & 151.65 & 0.00 & 41.72 & 0.01 & 33.05 & 0.10 & 38.50 & 0.03 \\
\hline 2011 & 46.51 & 0.00 & 50.21 & 0.00 & 68.59 & 0.00 & 54.37 & 0.00 & 37.69 & 0.03 & 48.29 & 0.00 \\
\hline
\end{tabular}

Table 6. Chi-squared test results for Academic Ranking of World Universities

\begin{tabular}{|c|c|c|c|c|c|c|c|c|c|c|c|c|c|c|}
\hline \multirow{2}{*}{$\begin{array}{l}\text { GDP } \\
\text { year }\end{array}$} & \multicolumn{2}{|l|}{ Total } & \multicolumn{2}{|c|}{ Alumni } & \multicolumn{2}{|c|}{ Award } & \multirow{2}{*}{$\frac{\text { HiCi }}{\chi^{2}}$} & \multicolumn{3}{|c|}{$\mathbf{N} / \mathbf{S}$} & \multirow{2}{*}{$\frac{\text { Pub }}{\chi^{2}}$} & \multicolumn{3}{|c|}{ PCP } \\
\hline & $\chi^{2}$ & $\mathrm{p}$ & $\chi^{2}$ & $\mathrm{p}$ & $\chi^{2}$ & $\mathrm{p}$ & & $\mathrm{p}$ & $\chi^{2}$ & $\mathrm{p}$ & & $\mathrm{p}$ & $\chi^{2}$ & $\mathrm{p}$ \\
\hline 2016 & 37.02 & 0.000 & 27.16 & 0.007 & 30.70 & 0.002 & 26.53 & 0.009 & 24.85 & 0.015 & 15.81 & 0.2 & 18.55 & 0.099 \\
\hline 2015 & 24.26 & 0.018 & 19.20 & 0.083 & 28.51 & 0.004 & 45.99 & 0.000 & 25.91 & 0. & 11.04 & 0. & 20.34 & 0.060 \\
\hline 2014 & 20.20 & 0.063 & 17.61 & 0.128 & 26.27 & 0.009 & 46.18 & 0.000 & 29.13 & 0.003 & 16.81 & 0. & 17.84 & 0.120 \\
\hline 2013 & 21.49 & 0.043 & 19.96 & 0.067 & 27.34 & 0.006 & 47.28 & 0.000 & 29.99 & 0.003 & 11.53 & 0.4 & 17.52 & 0.131 \\
\hline 2012 & 19.86 & 0.069 & 20.67 & 0.055 & 28.10 & 0.005 & 46.07 & 0.000 & 22.16 & 0.035 & 12.89 & 0.377 & 21.04 & 0.049 \\
\hline 2011 & 17.37 & 0.136 & 18.73 & 0.095 & 25.75 & 0.011 & 48.58 & 0.000 & 24.04 & 0.020 & 12.60 & 0.398 & 13.67 & 0.322 \\
\hline
\end{tabular}


The relationship between the Academic Ranking of World Universities and gross domestic product shared similar characteristics for two to three indicators. The alpha score is $\alpha=0.05$ with the degree of freedom, $\mathrm{df}=12$, and 21.026 is the value for rejecting the null hypothesis. The result shows that there is more or less relationship between the total score of the ranking and the gross domestic product with little significance year to year basis $\left(\chi^{2}=17.37, \mathrm{p}=0.136\right.$ in 2011; $\chi^{2}=19.86, \mathrm{p}=0.069$ in 2012; $\chi^{2}=21.49, \mathrm{p}=0.043$ in $2013 ; \chi^{2}=20.20, \mathrm{p}=0.063$ in $2014 ; \chi^{2}=24.26, \mathrm{p}=0.018$ in 2015; $\chi^{2}=37.02, \mathrm{p}=0.000$ in 2016). Indicators of Award, $\mathrm{HiCi}$ and $\mathrm{N} \& \mathrm{~S}$ are significantly related to the gross domestic product. Specifically, $\mathrm{HiCi}$, the number of highly cited researchers, are significantly related as compared with other indicators $\left(\chi^{2}=48.58,46.07,47.28,46.18,45.99, \mathrm{p}=0.000,26.53, \mathrm{p}=0.009\right)$.

\section{Discussion}

The result of correlation analysis shows that there is a weak relationship between the university performances and the economic development. This suggests that universities may contribute to the economic development to the extent of the specific roles they perform. It also suggests that there is a non-linear relationship between the university performances and the economic development. As previous studies documented that the specific intermediaries such as business industries (Bramwell\& Wolfe, 2008), research output (Bessette, 2003), university research collaboration (Berman, 1989, Perkman\& Walsh, 2007), university technology transfer offices (Seigel,et al, 2003) may serve as a bridge that connects universities and economic development. Hence, there is a weak non-linear relationship between the university performances and the economic development.

Since the relationship appeared to be weak nearing the zero, we confirmed through t-test that the non-linear relationship is statistically significant. Again, the t-test analysis shows that there is a non-linear relationship between the university performances and the economic development. This means that the role of the universities is significant in the current economic development. However, it is limited to make the above conclusion boldly. When we carefully looked at the indicators, specifically what kind of university performances, can have a significant relationship with the economic growth, indicators of measuring citations for both rankings bear highest correlation coefficient ( $r=0.288-0.440$ of Times Higher Education, $r=0.412-0.627$ of Academic Ranking of World Universities) among other indicators. Moreover, it appears that the number of publications and research does not necessarily affect economic growth as can be seen from the weak correlation of indicators: research of Times Higher Education $(r=0.141-0.279)$ and publication of Academic Ranking of World Universities ( $r=0.052-0.217)$. More correlation of citation and less correlation of research and publications implies that the quality of research and publication matters more than the number of publication and research. From the analysis, we also see that, specifically, publications and research in the field of natural science bear a stronger correlation. Further studies may compare the fields' research performance with the gross domestic product to test if natural science contributes to the economic growth more than any other fields of study.

To understand if the result of those analysis holds valid argument, we ran a test of independence or chi-square test. The result shows that the total score of each ranking does not bear a significant relationship with the gross domestic product. However, again citation related indicators are significantly related to the gross domestic product ( $\mathrm{p}=0.000$ ). It implies that the quality of the research of universities has a significant impact on the economic growth of the country.

Taken together, the result suggests that there is a significant non-linear relationship between the university performances and the economic development. In other words, the researching aspect of the universities play a necessary but not sufficient role in the economic development. The quality of the publications and research as reflected in the citation indicators of both rankings matters most for the performances of the universities and its contribution to economic development.

Moreover, the assumption of the contribution of universities in economic development holds true in general as we found the relationship between university performances and the economic development. This study is limited to the university performances measured by world university rankings: Times Higher Education and Academic Ranking of World Universities. It also does not include data from the time span of previous years till 2011.

\section{References}

Academic Ranking of World Universities. (8, August, 2018). Retrieved from http://www.shanghairanking.com/

Altbach, P. G. (2009). Peripheries and centers: research universities in developing countries. Asia Pacific Education Review, 10(1), 15-27. https://doi.org/10.1007/s12564-009-9000-9 9

Berman, E. M. (1990). The economic impact of industry-funded university R\&D. Research policy, 19(4), 349-355. https://doi.org/10.1016/0048-7333(90)90018-2 
Bessette, R. W. (2003). Measuring the economic impact of university-based research. The Journal of Technology Transfer, 28(3), 355-361. https://doi.org/10.1023/A:1024917601088

Bramwell, A., \& Wolfe, D. A. (2008). Universities and regional economic development: The entrepreneurial University of Waterloo. Research policy, 37(8), 1175-1187. https://doi.org/10.1016/j.respol.2008.04.016

Byun, K., Jon, J. E., \& Kim, D. (2013). Quest for building world-class universities in South Korea: Outcomes and consequences. Higher Education, 65(5), 645-659. https://doi.org/10.1007/s10734-012-9568-6

Cainelli, G., Evangelista, R., \& Savona, M. (2004). The impact of innovation on economic performance in services. The Service Industries Journal, 24(1), 116-130. https://doi.org/10.1080/02642060412331301162

Etzkowitz, H. (2003). Innovation in innovation: The triple helix of university-industry-government relations. Social science information, 42(3), 293-337. https://doi.org/10.1177/05390184030423002

Forida, R., \& Cohen, W. (1999). Engine or infrastructure? The university role in economic development. From industrializing knowledge. University-industry linkages in Japan and the United States, 589-610.

Goldstein, H., \& Renault, C. (2004). Contributions of universities to regional economic development: A quasi-experimental approach. Regional studies, 38(7), 733-746. https://doi.org/10.1080/0034340042000265232

Gyimah-Brempong, K., Paddison, O., \& Mitiku, W. (2006). Higher education and economic growth in Africa. The Journal of Development Studies, 42(3), 509-529. https://doi.org/10.1080/00220380600576490

Hazelkorn, E. (2009). Rankings and the battle for world-class excellence. Higher education management and Policy, 21(1), 1-22. https://doi.org/10.1787/hemp-v21-art4-en

Huang, F., Jin, L., \& Sun, X. (2009). Relationship between scale of higher education and economic growth in China. Asian Social Science, 5(11), 55. https://doi.org/10.5539/ass.v5n11p55

Huggins, R., \& Johnston, A. (2009). The economic and innovation contribution of universities: a regional perspective. Environment and Planning C: Government and Policy, 27(6), 1088-1106. https://doi.org/10.1068/c08125b

Kehm, B. M., \& Stensaker, B. (2009). University rankings, diversity, and the new landscape of higher education. Rotterdam: Sense Publishers.

Lin, T. C. (2004). The role of higher education in economic development: an empirical study of Taiwan case. Journal of Asian Economics, 15(2), 355-371. https://doi.org/10.1016/j.asieco.2004.02.006

Marginson, S. (2009). Open source knowledge and university rankings. Thesis Eleven, 96(1), 9-39. https://doi.org/10.1177/0725513608099118

Marginson, S. (2009). The knowledge economy and higher education: A system for regulating the value of knowledge. Innovación Educativa, 9(47), 63-71.

Marginson, S. (2010). The global knowledge economy and the culture of comparison in higher education. Quality assurance and university rankings in higher education in the Asia Pacific: Challenges for universities and nations, 23-55.

Mok, K. H., \& Chan, Y. (2008). International Benchmarking with the Best Universities: Policy and Practice in Mainland China and Taiwan. Higher Education Policy, 21(4), 469-486. https://doi.org/10.1057/hep.2008.21

Mueller, P. (2006). Exploring the knowledge filter: How entrepreneurship and university-industry relationships drive economic growth. Research policy, 35(10), 1499-1508. https://doi.org/10.1016/j.respol.2006.09.023

Olssen, M., \& Peters, M. A. (2005). Neoliberalism, higher education and the knowledge economy: From the free market to knowledge capitalism. Journal of education policy, 20(3), 313-345. https://doi.org/10.1080/02680930500108718

Park, H. W., \& Leydesdorff, L. (2010). Longitudinal trends in networks of university-industry-government relations in South Korea: The role of programmatic incentives. Research policy, 39(5), 640-649. https://doi.org/10.1016/j.respol.2010.02.009

Perkmann, M., \& Walsh, K. (2007). University-industry relationships and open innovation: Towards a research agenda. International Journal of Management Reviews, 9(4), 259-280. https://doi.org/10.1111/j.1468-2370.2007.00225.x

Power, D., \& Malmberg, A. (2008). The contribution of universities to innovation and economic development: in 
what sense a regional problem?. Cambridge Journal of Regions, Economy and Society, 1(2), 233-245. https://doi.org/10.1093/cjres/rsn006

Rhoades, G., \& Slaughter, S. (2004). Academic capitalism in the new economy: Challenges and choices. American Academic, 1(1), 37-59.

Roessner, D., Bond, J., Okubo, S., \& Planting, M. (2013). The economic impact of licensed commercialized inventions originating in university research. Research Policy, 42(1), 23-34. https://doi.org/10.1016/j.respol.2012.04.015

Schwartzman, S. (2007). Brazil's leading university. World class worldwide: Transforming research universities in Asia and Latin America, 143-172.

Siegel, D. S., Waldman, D., \& Link, A. (2003). Assessing the impact of organizational practices on the relative productivity of university technology transfer offices: an exploratory study. Research policy, 32(1), 27-48. https://doi.org/10.1016/S0048-7333(01)00196-2

Slaughter, S., \& Leslie, L. L. (1997). Academic capitalism: Politics, policies, and the entrepreneurial university. The Johns Hopkins University Press, 2715 North Charles Street, Baltimore, MD 21218-4319.

Times Higher Education. (8, August, 2018). Retrieved from https://www.timeshighereducation.com

Viracheat, I., \& Dash, T. R. (2011). Growth of higher education and its relationship with per capita gross domestic product in Cambodia. International Journal of Business and Social Science, 2(12), 53-62.

Wong, P. K., Ho, Y. P., \& Singh, A. (2007). Towards an "entrepreneurial university" model to support knowledge-based economic development: the case of the National University of Singapore. World Development, 35(6), 941-958. https://doi.org/10.1016/j.worlddev.2006.05.007

Xavier, C. A., \& Alsagoff, L. (2013). Constructing "world-class" as "global": a case study of the National University of Singapore. Educational Research for Policy and Practice, 12(3), 225-238. https://doi.org/10.1007/s10671-012-9139-8

Yonezawa, Akiyoshi. (2011) The "Global 30" and the Consequences of Selecting "World-Class Universities" in Japan. Paths to a World-Class University Lessons from Practices and Experiences. (Liu, N. C. W., Qi \& Cheng, Ying. Eds) The Netherlands: Sense Publisher. 